\title{
CMC and regulatory considerations for polyethylene glycol-modified protein therapeutics
}

\section{特集 医薬品開発における DDS の活用}

\author{
Susan Cannon-Carlson - David Wylie ${ }^{* 1)}$, Doug Kline ${ }^{* 2)}$, Doug Inloes ${ }^{* 1)}$
}

\begin{abstract}
蛋白修飾医薬品における $\mathrm{CMC}$ 要件
C 型肝炎ウイルス感染者は現在, 全世界で 2 億 7,000 万人と推定され，さらに年間 400 万人が新た に感染していると考えられている。C型肝炎ウイルス感染は慢性肝疾患の主な原因であり，米国およ びヨーロッパ諸国における肝牶移植の最も一般的な理由となっている。 ボリエチレンクリコール修 飾(以降ペダ化)インターフェロン(ペグインターフェロン アルファー2b： PEG-INTRON ${ }^{\natural}$ ，あるい はペタインターフェロン アルフォー2a : PEGASYS $\left.{ }^{\mathbb{B}}\right) の$ 単独あるいはリパビリンとの併用療法は. $\mathrm{C}$ 型肝炎ウイルス感染患者の標準療法となっている.これらのペグ化インターフェロンは，核となる インターフェロン分子のさまざまな部位にボリエチレングリコール(PEG)が一分子結合したモノぺ ク化蛋白のへテロな混合物，すなわち修飾部位異性体の混合物であるため，製造および特性解析に は CMC 部門の多大な努力が払われている.これら製造時および特性解析上の困難に対して, PEGINTRON ${ }^{8}$ の開発を通じて包括的に取り組んだ. 原蒀および製剂中のベク化インターフェロンに関す る広螌な特性解析および適切な製造管理方法の設定は， $\mathrm{CMC}$ 部門の開発戦略の土台となり，薬事承 認を得るという目的に適うものであった。

本研究は，PEG-INTRON ${ }^{刃}$ を楼成する修饰部位異性体を定量的に評価するための分析戦略につい て述べたものである。個々の修飾部位異性体を単離し，それぞれのぺク結合部位およびインビトロ生 物活性について解析した。この結果，異なるぺダ化反応により修飾部位異性体の分布が異なる混合物

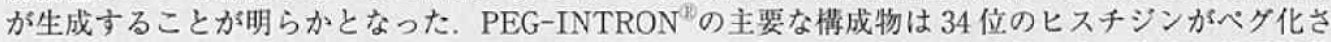
れたものであり、これは種々のモノペグ化インターフェロン中，最も生物活性の高い修飾部位異性体 であることが示された。 一方、リジン残基に PEG が結合した修飾部位異性体の抗ウイルス活性はき わめて低いものであった. したがって.PEG-INTRON ${ }^{\pi}$ と PEGASYS ${ }^{\mathbb{E}}$ はペグ化反応が異なることに より，それぞれ修飾部位異性体の混合物分布が異なり，また，インビトロ生物活性ブロファイルが異 なったと説明できる。
\end{abstract}

The hepatitis $\mathrm{C}$ virus (HCV) is currently estimated to infect over 270 million people worldwide, with up to 4 million people newly infected each year. It is the leading cause of chronic liver disease and the most common reason for liver transplantation in the USA and Europe. The pegylated interferons (peginterferon alfa-2b : PEG-INTRON ${ }^{18}$ and peginterferon alfa-2a : PEGASYS ${ }^{8}$ ), alone or in combination with ribavirin, are the current standard of care for patients with HCV. There are significant chemistry and manufacturing control $(\mathrm{CMC})$ challenges in the manufacture and characterization of the pegylated interferons since these therapeutic drugs are composed of heterogeneous mixtures of mono-pegylated proteins with differing sites of attachment of polyethylene glycol (PEG) to the core interferon molecule, termed "positional isomers". These CMC issues were comprehensively addressed during the development of PEG-INTRON ${ }^{R}$. Extensive characterization of the pegylated interferon in the drug substance and drug product, and the establishment of appropriate manufacturing controls, served as the foundation for a successful CMC strategy to obtain regulatory approval.

This study describes the analytical strategies for quantitating the positional isomer populations which comprise PEG-INTRON ${ }^{1}$. Individual positional isomers were also isolated and characterized with respect to site of pegylation and in vitro biological potency. It was determined that different pegylation chemistries result in different mixtures of positional isomers. PEG-INTRON ${ }^{18}$ is predominantly pegylated at histidine 34 , demonstrated to be the most biologically active positional isomer of the pegylated interferons. In contrast, the antiviral activities of positional isomers generated by attachment of PEG to lysine residues were significantly lower. Thus, the differences in pegylation chemistry between PEG-INTRON ${ }^{\ll}$ and PEGASYS ${ }^{1 /}$ result in different distributions of pegylated positional isomers and differential biological activity profiles in vitro.

Susan Cannon-Carlson $\cdot$ David Wylie ${ }^{* 1}$, Doug Kline ${ }^{* 2)}$, Doug Inloes ${ }^{* 1}$ key words: PEG-INTRON, positional isomers, CMC characterization, regulatory, hepatitis

\footnotetext{
*1) Department of Biotechnology Development, Schering Plough Research Institute, Union NJ

*2) Department of Pharmaceutical Development, Schering Plough Research Institute, Kenilworth NJ
} 
Hepatitis C virus (HCV), a single-stranded RNA virus in the Flaviviridae family discovered in 1989, is currently estimated to infect over 270 million people worldwide ${ }^{1}$, with up to 4 million people newly infected each year ${ }^{2)}$. It is the leading cause of chronic liver disease and the most common reason for liver transplantation in the USA and Europe ${ }^{3)}$. In industrialized countries, HCV accounts for $20 \%$ of cases of acute hepatitis, $70 \%$ of cases of chronic hepatitis, $40 \%$ of cases of end-stage cirrhosis, $60 \%$ of cases of hepatocellular carcinoma and $30 \sim 40 \%$ of liver transplants ${ }^{4)}$. The incidence of new symptomatic infections of $\mathrm{HCV}$ has been estimated to be $1 \sim 3$ cases $/ 100,000$ persons annually. The actual incidence of new infection is much higher, with the majority of the newly infected unaware that they carry the virus because they are not symptomatic or clinically ill. Over the next two decades, chronic HCV infection is predicted to become a major health care issue as patients who are currently asymptomatic or display relatively mild disease progress to endstage liver disease or develop hepatocellular carcinoma.

Since the early 1990s, the standard treatment for patients with chronic hepatitis $\mathrm{C}$ has been the administration of either interferon alfa- $2 b$ or interferon alfa- $2 \mathrm{a}$, sterile protein products generated by recombinant DNA technology with amino acid sequences identical to naturally occurring interferons belonging to the class II family of $\alpha$-helical cytokines, which possess antiviral and antiproliferative biological activities ${ }^{5)}$. However, the serum half-life of unmodified interferons is only $4 \sim 16$ hours $^{6)}$ necessitating a thrice-weekly dosing schedule to achieve pharmacologically active serum drug concentrations. Even with this frequent administration strategy, drug levels drop below detectable levels 24 hours after administration and interferon monotherapy produces sustained responses in only about $10 \sim 20 \%$ of patients $^{7)}$. The addition of oral ribavirin, a synthetic guanosine nucleoside analog with activity against RNA viruses, to the interferon (IFN) treatment regimen improved sustained response rates to 29 $\sim 65 \%^{8.9)}$. Therefore, combination therapy is the preferred course of treatment.

However, even with the addition of ribavirin to the interferon therapy regimen and its concomittent improvement in efficacy, major pharmacokinetic and pharmacodynamic limitations of the regimen remain. This has led to the development of longer acting IFN formulations, achieved by the covalent attachment of polyethylene glycol (PEG), a large, highly soluble, nontoxic adduct which has been found to retard clearing of proteins from the bloodstream and to improve serum half-life. A number of studies exist in the literature showing that pegylation modifies the pharmacological properties of proteins by shielding antigenic and immunogenic epitopes, shielding receptormediated uptake by the reticuloendothelial system (RES), and preventing recognition and degradation by proteolytic enzymes ${ }^{10-20)}$. While the large amorphous nature of PEG can adversely impact the specific activity of modified biologicals in vitro, presumably by obscuring receptor-binding or active sites $^{21}$, this reduced activity is believed to be offset by increased availability in vivo. Pegylated interferon alfa-2b (peginterferon alfa-2b : PEGINTRON $^{\circledR}$, Schering Corp, Kenilworth, NJ, USA) and pegylated interferon alfa-2a (peginterferon alfa-2a : PEGASYS ${ }^{\circledR}$, F Hoffman-La Roche, Nutley, NJ, USA), alone or in combination with ribavirin, have half lives that permit once-weekly dosing alone and have become the new standard of care for patients with $\mathrm{HCV}^{22.23)}$. Clinical trials have shown that both pegylated interferons produce sustained viral response rates superior to those achieved with their respective standard IFN alfas $^{24 \sim 27)}$.

Many chemistries have been developed for attaching PEG polymer to amino, carboxylate, and thiol groups of proteins under mild conditions, but pharmaceutical products developed to date largely have used urethane or amide linkages between PEG and the protein amine and histidine groups. The product of these reactions is usually a hetero- 
geneous mixture of monopegylated proteins with differing sites of PEG attachment. The relative proportions of these positional isomers reflect local variances in amino group exposure and pKa and can be altered by a number of variables, including pegylation reaction $\mathrm{pH}^{28}$.

In vitro $\mathrm{CMC}$ characterization of the pegylated product is critical to provide a basis for establishing consistency in the manufacturing process, the determination of product physico-chemical properties and biological activities, and an assessment of product purity and impurities. There are significant challenges in the characterization of pegylated proteins, due to the population heterogeneity with respect to the stoichiometry and positions of the attached PEG molecules and due to the inherent polydispersity of PEG itself ${ }^{29)}$. For well-characterized pegylated biomolecules, it is important to develop and validate suitable analytical assays to characterize, monitor and control the resultant product composition.

The above considerations for pegylated proteins were comprehensively addressed during the development of peginterferon alfa-2b (PEGINTRON $^{\mathbb{E}}$ ). Extensive characterization and control of the pegylated interferon in the drug substance and drug product, as well as establishment of appropriate control of the manufacturing processes, served as the foundation for a successful CMC strategy to obtain regulatory approval of PEG-INTRON ${ }^{\circledR}$. This paper summarizes the approaches taken to address the CMC technical and regulatory challenges during peginterferon alfa-2b development.

\section{Materials and methods}

\section{Pegylation reaction and purification of PEG $_{12 k}-$ IFN alfa-2b}

For the pegylation characterization studies, recombinant human IFN alfa-2b (IFN alfa-2b) was supplied by Schering-Plough (Union, NJ, USA). The pegylation linker used to attach the PEG to the protein, $\mathrm{PEG}_{12.000}$ Succinimidyl Carbonate (SC-
$\mathrm{PEG}_{12 \mathrm{k}}$ ), was obtained from Nektar Therapeutics (Huntsville, AL, USA). As previously published ${ }^{28)}$, pegylated interferon is produced by incubation of IFN alfa-2b with SC-PEG ${ }_{12 \mathrm{k}}$ (4 moles per mole IFN) at $\mathrm{pH} 6.5$ and $22^{\circ} \mathrm{C}$ for 2 hours. The reaction is terminated by addition of glycine. Monopegylated interferon (mono-PEG-IFN) is then resolved from unmodified and di-pegylated forms by anion exchange chromatography to generate $\mathrm{PEG}_{12 \mathrm{k}}$-IFN alfa-2b.

\section{Analytical SE-HPLC of $P G_{12 k}-I F N$ alfa-2b}

Unmodified, mono-pegylated, and di-pegylated forms of IFN alfa-2b were resolved by size exclusion chromatography (SE-HPLC) on Superdex $200 \mathrm{HR}$ (10 mm by $30 \mathrm{~cm}, 13 \mu \mathrm{m}$ particle size, Amersham) with a mobile phase containing 20 $\mathrm{mM}$ sodium phosphate, $\mathrm{pH} 7.2,150 \mathrm{mM} \mathrm{NaCl}$ and a column flow rate of $0.5 \mathrm{~mL} / \mathrm{min}$. Relative retention times were compared with those of a set of synthetic polymer standards to calculate the Stokes radius (apparent size).

\section{Analytical IE-HPLC of PEG $_{12 \mathrm{k}}-\mathrm{IFN}_{\text {alfa-2b }}$}

To determine the distribution of mono-pegylated positional isomers, aliquots of $\mathrm{PEG}_{12 \mathrm{k}}-\mathrm{IFN}$ alfa-2b were adjusted to $\mathrm{pH} 4.7$ and $6 \mathrm{mS} / \mathrm{cm}$ and resolved by cation exchange chromatography on an SP-5PW cation exchange column $(7.5 \times 75$ $\mathrm{mm}$, Toso Haas, Montgomeryville, PA, USA) as previously described ${ }^{30)}$.

\section{Purification of mono-pegylated positional isomers}

Pools of purified, mono-pegylated positional isomers were obtained for characterization by cation exchange chromatography ${ }^{28)}$. The $\mathrm{PEG}_{12 \mathrm{k}}{ }^{-}$ IFN alfa-2b product was adjusted to $\mathrm{pH} 4.7$ and 6 $\mathrm{mS} / \mathrm{cm}$ and applied to a column pre-packed with Mono-S (HR 10/10, Amersham-Pharmacia) and equilibrated with $40 \mathrm{mM}$ sodium acetate, $\mathrm{pH} 4.7$. $25 \mathrm{mM}$ sodium chloride at $4^{\circ} \mathrm{C}$. After washing with equilibration buffer $(5 \mathrm{cv})$, three peaks of mono-PEG-IFN were eluted with a gradient $(20 \mathrm{cv})$ to $250 \mathrm{mM} \mathrm{NaCl}$. Unmodified IFN was 
then eluted with a gradient $(3 \mathrm{cv})$ to $750 \mathrm{mM}$ $\mathrm{NaCl}$. The column flow rate was maintained at $30 \mathrm{~cm} / \mathrm{hr}$, and column elution fractions $(0.25 \mathrm{cv})$ were collected. Separate pools made on the basis of offline absorbance measurements were dialyzed against equilibration buffer, and each was applied to a second Mono-S column equilibrated as before. After washing with equilibration buffer $(5 \mathrm{cv})$. a single major peak of purified, mono-pegylated positional isomer was eluted with a gradient $(30$ cv) to $200 \mathrm{mM} \mathrm{NaCl}$.

\section{Peptide mapping and identification of pegylated residues}

Purified positional isomer pools were digested by incubating $\mathrm{PEG}_{12 \mathrm{k}}-\mathrm{IFN}$ alfa-2b with trypsin ( 5 $\mu \mathrm{L}$ of $1 \mathrm{mg} / \mathrm{mL}$ solution in $0.1 \mathrm{mM} \mathrm{HCl}$ ) at $\mathrm{pH}$ 7.8 and $37^{\circ} \mathrm{C}$ for 2 hours. At this point, a second identical aliquot of trypsin was added together with an aliquot of endoproteinase Glu-C (10 $\mu \mathrm{L}$ of $1 \mathrm{mg} / \mathrm{mL}$ solution in phosphate-buffered saline). Incubation was continued overnight. The reaction was terminated by immediate purification of pegylated peptides by SE-HPLC. Pegylated peptides were isolated from the protease digests and collected in $0.5-\mathrm{mL}$ fractions by SE-HPLC on Superdex 200 (HR 10/30, Amersham Pharmacia) in $100 \mathrm{mM}$ sodium phosphate, $\mathrm{pH}$, $150 \mathrm{mM}$ sodium chloride at a column flow rate of $0.5 \mathrm{~mL} / \mathrm{min}$. The purified pegylated peptides were identified by two assays : (1) $\mathrm{N}$-terminal sequence analysis and (2) MALDI-MS before and after treatment with neutral hydroxylamine.

\section{Cytopathic effect assay}

To measure antiviral activity, the ability of the pegylated interferon to prevent cell death in vitro by infection with encephalomyocarditis virus was analyzed as per Mossman ${ }^{31}$.

\section{STAT1 translocation assay}

To provide another measurement of antiviral activity, the STAT1 translocation assay was performed as described ${ }^{32)}$. This assay measures
STAT (signal transduction and activator of transcription)-mediated signal transduction associated with IFN interaction with its cellular receptor. High STAT nuclear translocation results in higher levels of IFN-response gene mRNA and higher antiviral activity. Human hepatoma (Huh-7) cells were cultured in Dulbecco's modified Eagle's medium, 10\% fetal bovine serum, $2 \mathrm{mM}$ GlutaMax-1, 100 units/mL penicillin/streptomycin, and nonessential amino acids. Cells $(10,000$ cells/well) were seeded overnight in 96-well Packard black view plates (Packard Instrument Co.). 3-Fold serial dilutions of the samples ere prepared in Dulbecco's modified Eagle's medium and incubated with cells at $37^{\circ} \mathrm{C}$ in $5 \sim 6 \% \mathrm{CO}_{2}$ for $30 \mathrm{~min}$. The cells were washed with phosphatebuffered saline, fixed with $3.7 \%$ formaldehyde, and permeabilized with $0.5 \%$ Triton $\mathrm{X}-100$. The cells were then incubated with either a polyclonal anti-STAT1 p84/p91 (clone E-23 : Santa Cruz Biotechnology, Inc., Santa Cruz, CA, USA) or a polyclonal anti-STAT2 (clone C-20 : Santa Cruz Biotechnology) primary antibody for 1 hour at room temperature. The cells were sequentially washed with phosphate-buffered saline and $0.01 \%$ Tween 20. They were then incubated for 1 hour with a mixture of Alexa Fluor ${ }^{\circledR} 488$-conjugated goat anti-rabbit IgG (Molecular Probes, Inc., Eugene, OR, USA) and Hoechst 33342 (Molecular Probes). The cells were again washed with $0.01 \%$ Tween 20 and phosphate-buffered saline. The plates were imaged on the ArrayScan ${ }^{\circledR}$ II High Content Screening System (Cellomics, Pittsburgh, PA, USA) with a $10 \mathrm{X}$ objective using the ArrayScan version 2.1 software (Cellomics). The resulting images were processed using the Cytoplasm to Nucleus Translocation Application software (Cellomics). The cytonuclear difference, defined as the difference in fluorescence intensity of the target STAT in the nuclear region minus the cytoplasmic region, was used as a measure of STAT translocation. Cytoplasmic and nuclear STAT1 levels were also examined for each cytonuclear difference determination. 
Tab. 1 Commercially available pegylation linkers

\begin{tabular}{c|c|c|c}
\hline Linker & $\begin{array}{c}\text { Preferred } \\
\text { substrate }\end{array}$ & Bond formed & Optimal pH \\
\hline mPEG succinimidyl proprionate & Amine & Amide & Basic \\
\hline mPEG2-N-hydroxysuccinimide & Amine & Amide & Basic \\
\hline \multirow{2}{*}{ mPEG succinimidyl carbonate } & Amine & Urethane & Basic \\
\cline { 2 - 4 } & Histidine & Carboxyalkyl & Neutral \\
\hline mPEG-benzyltriazole carbonate & Histidine & Carboxyalkyl & Neutral \\
\hline mPEG-maleimide & Cysteine & Thiol & Neutral \\
\hline mPEG-propionaldehyde & $\alpha$-Amine & Amide & Basic \\
\hline
\end{tabular}

\section{Results}

\section{Linker chemistry}

Polyethylene glycol is a linear or branched polyether terminated by hydroxyl groups and with the general structure :

$$
\mathrm{HO}-\left(\mathrm{CH}_{2} \mathrm{CH}_{2} \mathrm{O}\right)_{\mathrm{n}}-\mathrm{CH}_{2} \mathrm{CH}_{2}-\mathrm{OH}
$$

To couple PEG to a protein, one end is blocked via methylation to form $\mathrm{MPEG}$ :

$$
\mathrm{CH}_{3} \mathrm{O}-\left(\mathrm{CH}_{2} \mathrm{CH}_{2} \mathrm{O}\right)_{n}-\mathrm{CH}_{2} \mathrm{CH}_{2}-\mathrm{OH}
$$

The mPEG is then activated by preparing a derivative having a functional group at the other termini ${ }^{10)}$. A wide variety of linkers are available with chemistries that target specific moieties on proteins (specific amino acid side chains and the N-terminal amine, see Tab. 1). One commonly utilized linker chemistry employs N-hydroxysuccinimide (e.g., NHS-PEG), which forms amide bonds with lysine side chains $\left(\varepsilon^{-}\right.$ amine) and the $\mathrm{N}$-terminus of the peptide chain $\left(\alpha\right.$-amine). Peginterferon alfa-2a (PEGASYS $\left.^{\mathbb{R}}\right)$ is manufactured using this chemistry. Manufacture of peginterferon alfa-2b (PEG-INTRON ${ }^{\mathrm{Q}}$ ) utilizes succinimidyl carbonate (SC-PEG), which forms urethane bonds with amine groups ( $\mathrm{N}$-terminal cysteine and $\varepsilon$-amino group of lysine) and carboxyalkyl bonds with the imidazole group of histidine of the IFN alfa-2b molecule.

SC-PEG and NHS-PEG differ in their specificity as a function of $\mathrm{pH}$. In general, both linkers react most rapidly in basic solutions (e.g. $\mathrm{pH}$ 10) to form bonds with primary amines. At lower reaction $\mathrm{pH}$ values, both linkers react more slowly. In addition, SC-PEG exhibits a change in specificity with decreasing $\mathrm{pH}$. Under mildly acidic conditions ${ }^{28)}$ the preferred substrate for SC-PEG changes from lysine to histidine (Fig. 1). This is shown clearly with a model pegylation reaction system using synthetic peptides (Tab. 2). In the model system, the peptide containing histidine, but no lysine, is fully pegylated at $\mathrm{pH}$ 6.5. At this $\mathrm{pH}$, only $13 \%$ of the lysine-containing peptide is pegylated. The inverse is true at $\mathrm{pH}$ 10.0. Therefore, pegylation at a mildly acidic $\mathrm{pH}$ results primarily in histidine pegylation, while amine groups are the preferred substrate at basic $\mathrm{pH}$.

The $\mathrm{pH}$-dependence of the pegylation specificity is also observed with proteins. At $\mathrm{pH} 6.5$, the condition used during manufacture of $\mathrm{PEG}_{12 \mathrm{k}}-\mathrm{IFN}$ alfa-2b, approximately $50 \%$ of the IFN alfa-2b is pegylated at histidine 34 (His34).

\section{Size of PEG}

In addition to specific linker chemistries, activated PEG linkers are available with a range of PEG molecular weights (MWs), the most common being linear PEG groups with $\mathrm{MWs}$ of $5 \mathrm{kDa}$, $12 \mathrm{kDa}, 20 \mathrm{kDa}$ and $30 \mathrm{kDa}$ and branched PEG groups with $\mathrm{MWs}$ of $20 \mathrm{kDa}$ and $40 \mathrm{kDa}$. Two considerations affect the choice of optimal size. Larger chains can retard glomerular elimination, thereby increasing serum half-life. However, PEG chains can also inhibit the substrate protein's activity. Generally, this inhibition increases with the size of the PEG. Tab. 3 lists PEG sizes used in 


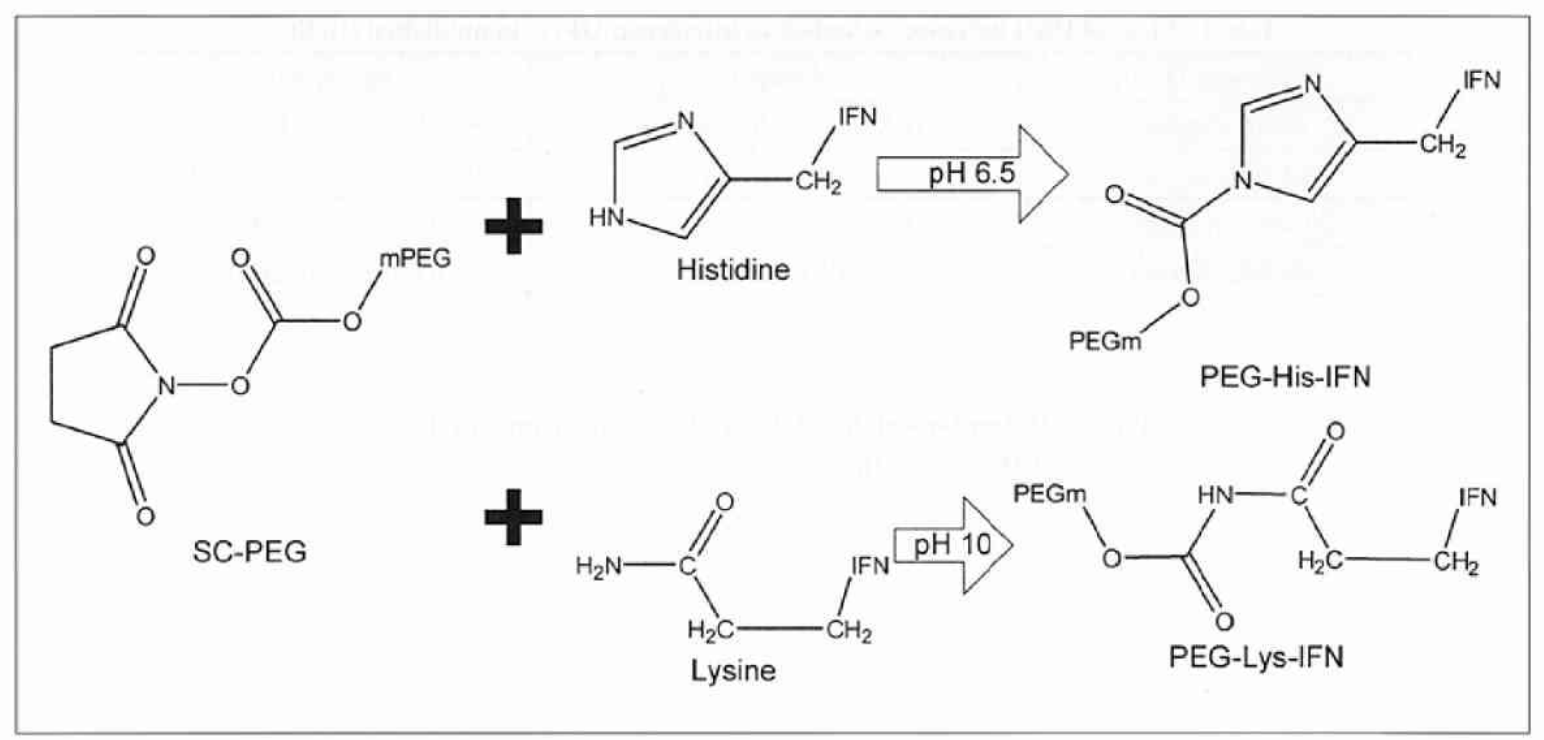

Fig. 1 Effect of $\mathrm{pH}$ on preferred pegylation substrate for SC-PEG

published studies of pegylated interferon.

\section{Hydrodynamic radius of pegylated interferon}

PEG is a hydrophilic polymer with no compacting secondary structure. In addition, each ethylene glycol subunit tends to associate with 2 $\sim 3$ water molecules. As a result of these properties, the apparent molecular weight calculated from SE-HPLC is much higher than the sum of the PEG and protein masses (Tab. 4).

In general, cytokines are eliminated from the body by specific and nonspecific mechanisms. Specific mechanisms include cell surface receptormediated uptake or binding to and clearance of soluble cytokine-receptor complexes with subsequent uptake by specific cell types. It has been shown in animal model systems that the kidney plays a significant role in clearance. An extensive literature exists on the characterization of the glomerular sieving profiles of the kidneys in man, as part of analyses of abnormal permeability in patients with glomerulonephritis. A study performed specifically to determine the clearance rates of PEG groups of different sizes found that clearance decreased from $100 \%$ and approached $0 \%$ as the Stokes radius increased from 25 to 50 angstroms ${ }^{33)}$. The Stokes radius of $\mathrm{PEG}_{12 \mathrm{k}}-\mathrm{IFN}$
Tab. 2 Effect of reaction $\mathrm{pH}$ on extent of pegylation of synthetic peptides by SC-PEG

\begin{tabular}{|c|c|c|}
\hline Synthetic peptide sequence & Reaction $\mathrm{pH}$ & $\begin{array}{c}\text { Extent } \\
\text { of reaction }\end{array}$ \\
\hline Ac-FQKAETIP-NH ${ }_{2}$ & 6.5 & $13 \%$ \\
\hline Ac-FQKAETIP-NH ${ }_{2}$ & 10.0 & $100 \%$ \\
\hline $\mathrm{Ac}-\mathrm{DHDFGFPQ}-\mathrm{NH}_{2}$ & 6.5 & $100 \%$ \\
\hline Ac-DHDFGFPQ- $\mathrm{NH}_{2}$ & 10.0 & $24 \%$ \\
\hline
\end{tabular}

The pepticles were blocked at both termini. The only possible substrate for SC-PEG in each peptide is underlined ( $\mathrm{K}=\mathrm{lysine}, \mathrm{H}=$ histidine).

alfa-2b is 46.4 angstroms. Tab. 4 shows that the impact of PEG MW is somewhat additive with respect to Stokes radius. Because PEGASYS ${ }^{\circledR}$ is pegylated with branched $40 \mathrm{kDa}$ PEG, the Stokes radius of $\mathrm{PEG}_{40 \mathrm{k}}-\mathrm{IFN}$ alfa-2a can be predicted to be similar to that for di-PEG-IFN alfa-2b generated with $20 \mathrm{kDa}$ linear PEG (approximately 80 angstroms). Therefore, both $\mathrm{PEG}_{40 \mathrm{k}}-\mathrm{IFN}$ alfa-2a (branched $40 \mathrm{kDa} P E G$ ) and $P G_{12 \mathrm{k}}$-IFN alfa-2b (linear $12 \mathrm{kDa}$ PEG) will display retarded renal clearance through the glomerular membrane of the kidneys.

\section{Control of pegylation}

At the end of the pegylation reaction between SC-PEG ${ }_{12 k}$ and IFN alfa-2b, SE-HPLC detects a 
Tab. 3 Sizes of PEG polymers attached to interferon (IFN) in published studies

\begin{tabular}{c|c|c}
\hline PEG size $(\mathrm{Da})$ & Protein & Reference \\
\hline 5,000 (linear) & IFN alfa-2a, IFN alfa-2b & Monkarsh, 1997 \\
\hline 12,000 (linear) & IFN alfa-2b & Wylie, 2001 : Grace, 2001 \\
\hline 20,000 (branched) & IFN alfa-2a, IFN alfa-2b & Grace et al., 2005 \\
\hline 20,000 (linear) & IFN alfa-2b & Grace et al., 2005 \\
\hline
\end{tabular}

Tab. 4 Molecular weight, Stokes radius, and serum half-life of IFN-based therapeutics

\begin{tabular}{c|c|c|c}
\hline Protein (MW) & PEG MW & $\begin{array}{c}\text { Calculated } \\
\text { Stokes radius }(\AA)\end{array}$ & $\begin{array}{c}\text { Apparent MW } \\
(\mathrm{kDa})\end{array}$ \\
\hline IFN alfa-2b $(23 \mathrm{kDa})$ & None & 21.2 & 23.1 \\
\hline IFN alfa-2b (23 kDa) & $5 \mathrm{kDa}$ (linear) & 33.6 & 73.3 \\
\hline IFN alfa-2b $(23 \mathrm{kDa})$ & $12 \mathrm{kDa}$ (linear) & 46.4 & 165.6 \\
\hline IFN alfa-2b (23 kDa) & $20 \mathrm{kDa}$ (branched) & 56.5 & 272.3 \\
\hline IFN alfa-2b $(23 \mathrm{kDa})$ & $20 \mathrm{kDa}$ (linear) & 60.3 & 320.6 \\
\hline $\begin{array}{c}\text { IFN alfa-2b }(23 \mathrm{kDa}) \\
(\text { di-PEG-IFN) }\end{array}$ & $2 \times 20 \mathrm{kDa}$ (linear) & 79.4 & 639.7 \\
\hline
\end{tabular}

The Stokes radii were calculated by SE-HPLC calibrated against standard curves generated using polymers with known Stokes radii ${ }^{32}$. Data provided are for monopegylated interferon and for di-pegylated interferon (di-PEG-IFN).

mixture of unmodified interferon, mono-pegylated interferon and di- and multi-pegylated interferon. In addition, the linker itself is hydrolysed by aminolysis in aqueous systems, generating free NHS. The reaction continues until the linker is consumed, either by reaction with protein, aminolysis, or termination using a small molecule substrate such as glycine. Initially the only protein substrate for the linker is unmodified interferon. As the reaction proceeds, however, additional pegylation of previously pegylated interferon occurs at an increasing rate. This complexity requires that the reaction be optimized and tightly controlled.

At the onset of any reaction optimization, the desired product must be identified. For many pegylated proteins, including $\mathrm{PEG}_{12 \mathrm{k}}-\mathrm{IFN}$ alfa-2b, the mono-pegylated form has a distinctly higher specific activity than multi-pegylated forms, most likely due to increased steric interference between interferon and its cellular receptors as more of the protein structure is shielded by multiple attached PEG groups. In addition, post-reaction purification considerations must be taken into account. In the case of $\mathrm{PEG}_{12 \mathrm{k}}-\mathrm{IFN}$ alfa-2b, the greatest purification challenge is the removal of the di-pegylated interferon (di-PEG-IFN) from the mono-pegylated form (mono-PEG-IFN). Therefore the optimal product mix maximizes the ratio of mono-PEG-IFN to di-PEG-IFN.

With a given protein and linker, optimization typically involves four variables : reaction $\mathrm{pH}$, the molar ratio of linker to IFN, temperature, and time. As shown in Tab. 2, pH affects both the site and extent of the reaction. The remaining variables (molar ratio, temperature, time) control the extent of pegylation only.

The pegylation reaction products were monitored over time by the SE-HPLC assay to generate a reaction kinetic profile (Fig. 2). From this it can be concluded that $90 \%$ of the maximal level of mono-pegylated interferon is generated relatively early in the reaction (120 minutes in Fig. 2). Beyond this point, the ratio of mono- 


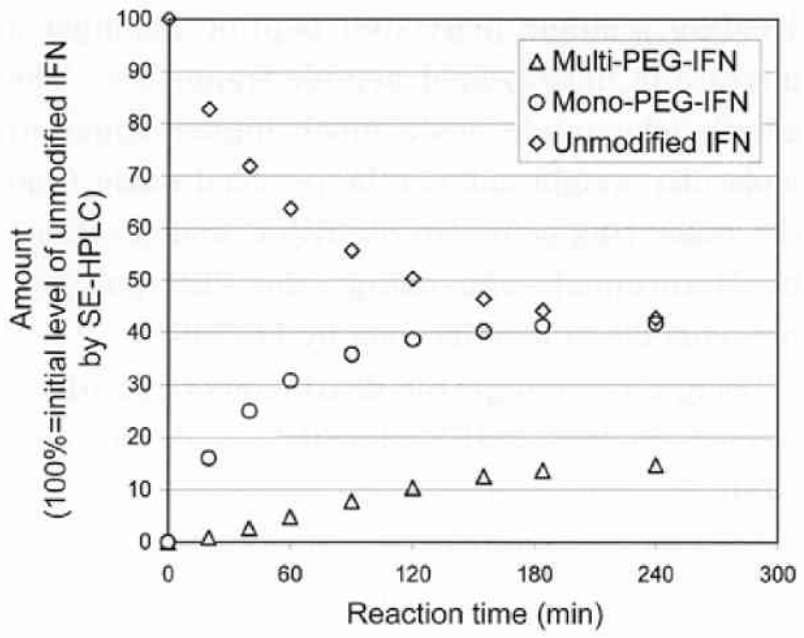

Fig. 2 Levels of substrate and products during pegylation reaction for $\mathrm{PEG}_{12 \mathrm{k}}-\mathrm{IFN}$ alfa-2b

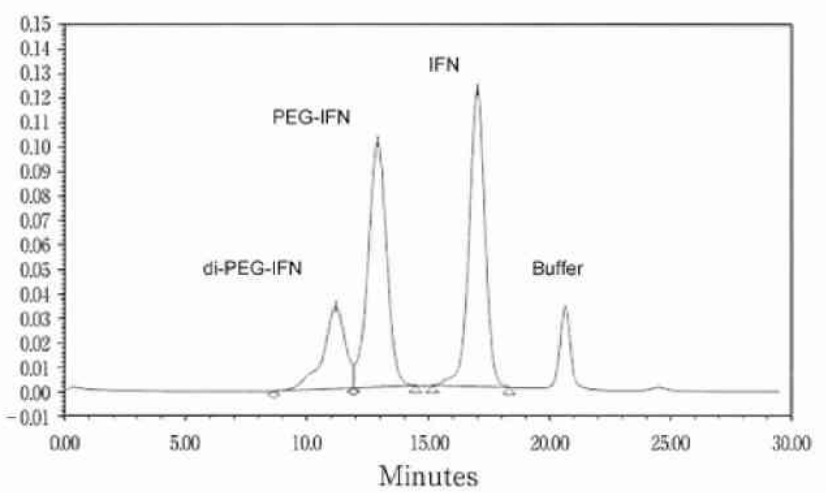

Fig. 3 SE-HPLC analysis of pegylation reaction product for $\mathrm{PEG}_{12 \mathrm{k}}-\mathrm{IFN}$ alfa-2b

PEG-IFN to di-PEG-IFN decreases substantially with little increase in mono-pegylated interferon, while the population of multi-pegylated interferon grows. The SE-HPLC assay provides a useful tool to both characterize the pegylation reaction and achieve an optimal product mix. Based on the reaction kinetic profile, the time for performing the pegylation reaction is controlled within specified limits to assure batch-to-batch consistency of the various pegylated forms.

Although $\mathrm{pH}$ can be used to control the rate and extent of pegylation, in the manufacture of $\mathrm{PEG}_{12 \mathrm{k}}-\mathrm{IFN}$ alfa-2b it is used instead as a selecting agent to encourage pegylation of His34. By using the combination of linker chemistry (SC-
PEG) and $\mathrm{pH}$ to target specific side chains, one can rationally design the pegylation of interferon.

\section{CMC challenges}

PEG-INTRON ${ }^{\circledR}\left(\mathrm{PEG}_{12 \mathrm{k}}-\mathrm{IFN}\right.$ alfa-2b), like most pegylated therapeutics, is a mixture of mono-pegylated proteins with differing sites of attachment. The product is the sum of contributions from these various positional isomer populations, which differ in structure and function. Characterization of the drug substance is critical to (1) maintain control of the composition, and therefore the quality, of the drug and (2) monitor manufacturing consistency.

\section{(1) Extent of pegylation and purification}

As shown in Fig. 2, the pegylation reaction product is a mixture of unmodified and pegylated interferon forms. At the end of the pegylation reaction, size exclusion (SE)-HPLC analysis (Fig. $3)$, shows that the extent of the reaction yields similar levels of unmodified and mono-pegylated forms and lower levels of multi-pegylated forms of interferon.

Since the sites of attachment are charged residues that are neutralized by the reaction, the various unmodified and pegylated forms of interferon differ slightly by charge. This facilitates the resolution of the unmodified, mono-pegylated, and di-pegylated forms by anion exchange chromatography in the purification process to yield a relatively pure preparation of mono-pegylated interferon free of other forms. SE-HPLC analysis is used to monitor the removal of unmodified and multi-pegylated interferon at the end of the purification (Fig. 4)

\section{(2) Sites of pegylation}

Since SE-HPLC resolves on the basis of molecular size, the purified, mono-pegylated product shown in Fig. 4 appears as a single peak. However, it actually is comprised of a heterogeneous mixture of positional isomers, differing in the site of attachment of PEG. Although all possess the same net charge, differences in the sites of attachment are reflected in differing electrostatic 


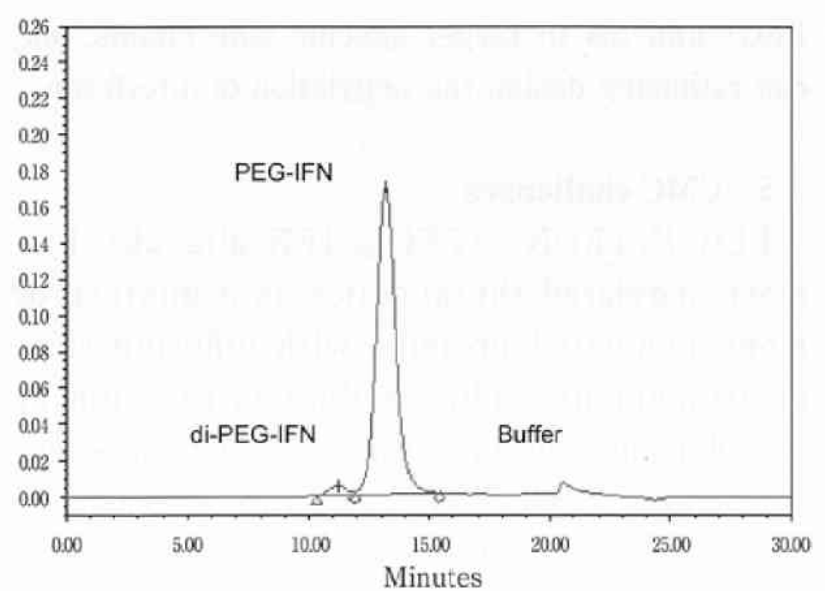

Fig. 4 SE-HPLC analysis of PEG $_{12 k \mathrm{k}}-$ IFN alfa-2b after purification by anion exchange chromatography

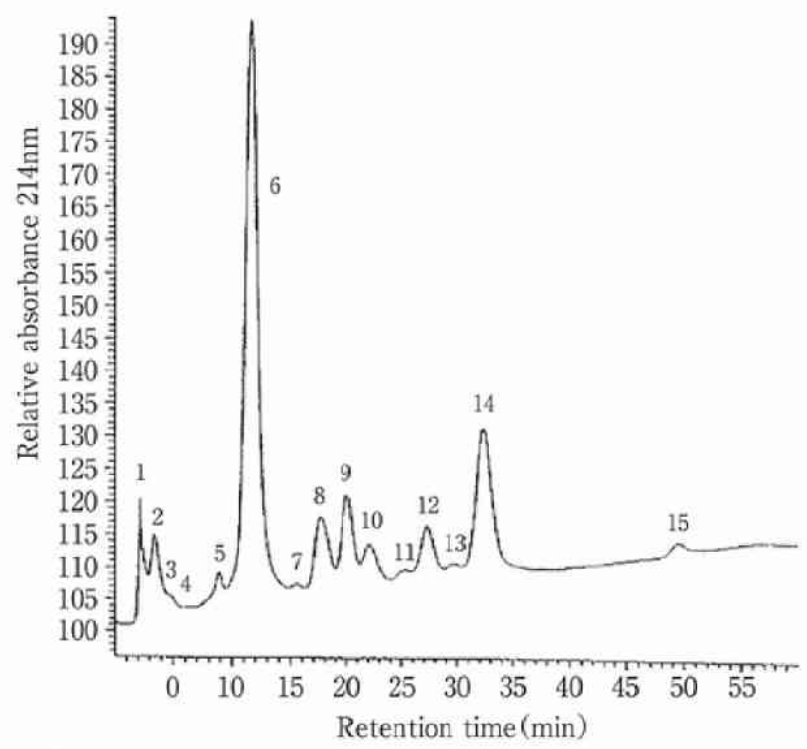

Fig. 5 Ion exchange (IE) HPLC analysis of purified PEG $_{22 \mathrm{k}}-\mathrm{IFN}$ alfa-2b

The peaks are numbered to reflect sequential elution of different positional isomers.

potential fields, which can be resolved by IEHPLC (Fig. 5).

The sites of pegylation in the $\mathrm{PEG}_{12 \mathrm{k}}$-IFN alfa-2b drug product were determined by a peptide mapping scheme that exploits the unique properties of pegylated peptides. Prior to enzymatic digestion, positional isomers were purified by preparative IE-HPLC. Each pure monopegylated positional isomer was then digested yielding a single pegylated peptide amongst a mixture of unpegylated peptide fragments. The pegylated peptide has a much higher apparent molecular weight and can be resolved easily from the other fragments by SE-HPLC and identified by $\mathrm{N}$-terminal sequencing (the PEG polymer prevents direct identification by LC/MS).

Using this strategy, the distribution of positional isomers in $\mathrm{PEG}_{12 \mathrm{k}}$-IFN alfa-2b was determined (Tab. 5). The primary site of conjugation (approximately $50 \%$ of all the positional isomers) is on His $34^{28.30 .34 \cdot 35)}$. The remaining positional isomers are distributed among Cys1 ( $\alpha$-amine) and the various lysine residues ( $\varepsilon$-amine).

\section{(3) Activity of pegylated interferon}

Consistent with the modification of most biologically active proteins, pegylation of the IFN core protein results in the loss of in vitro biological activity $^{36)}$. The antiviral (cytopathic effect) activity of $\mathrm{PEG}_{12 \mathrm{k}}$-IFN alfa-2b is about $28 \%$ (by weight of the IFN alfa- $2 \mathrm{~b}$ core protein) compared with unmodified IFN alfa-2b (Tab. 5). The relation of pegylation sites to receptor binding sites for IFN alfa-2b is shown in Fig. 6. The bulk of biological activity for $\mathrm{PEG}_{12 \mathrm{k}}-\mathrm{IFN}$ alfa-2b is derived from the His34 positional isomer, which has been shown to be the most active positional isomer, possessing approximately $37 \%$ of the antiviral activity of IFN alfa- $2 b^{34)}$. In contrast, the antiviral activities of positional isomers involving urethane bonds with Lysine ( $\varepsilon$-amine) or Cysteine ${ }_{1}(\alpha$-amine) range from $6 \%$ to $15 \%$ with two exceptions (Lys133 at $32 \%$ and Lys134 at 25\%), both of which are minor positional isomers. The median effective dose $\left(\mathrm{ED}_{50}\right)$ of each positional isomer required to translocate STAT1 shows the same trends as the cytopathic effect activities.

The biological activity of $\mathrm{PEG}_{40 \mathrm{k}}$-IFN alfa-2a is $1 \%$ that of unmodified IFN $^{32}$. The approximately 25 -fold difference in in vitro biological activities between $\mathrm{PEG}_{40 \mathrm{k}}$-IFN alfa-2b and $\mathrm{PEG}_{12 \mathrm{k}}-\mathrm{IFN}$ alfa-2b arises from differences in pegylation chemistry. $\mathrm{PEG}_{40 \mathrm{k}}-\mathrm{IFN}$ alfa-2a is generated using $\mathrm{N}$-hydroxysuccinimide (e.g. NHS-PEG) at basic 
Tab.5 Distribution of positional isomers in $\mathrm{PEG}_{12 \mathrm{k}}-\mathrm{IFN}$ alfa-2b

\begin{tabular}{|c|c|c|c|c|}
\hline $\begin{array}{l}\text { Residue linked } \\
\text { to PEG }\end{array}$ & $\begin{array}{l}\text { Peak } \\
\text { No. }\end{array}$ & Abundance & $\begin{array}{c}\text { Cytopathic effect } \\
\text { activity }\end{array}$ & $\begin{array}{c}\text { STAT1 } \\
\text { translocation } \\
\mathrm{ED}_{50}(\mathrm{ng} / \mathrm{mL})\end{array}$ \\
\hline Histidine $_{34}$ & 6 & $\sim 50 \%$ & $37 \%$ & 1.3 \\
\hline Cysteine $_{1}$ & 14 & $\sim 13 \%$ & $11 \%$ & 26.3 \\
\hline Lysine $_{121}$ & 9 & $\sim 7 \%$ & $9 \%$ & 7.4 \\
\hline Lysine $_{31}$ & 2 & $\sim 5 \%$ & $13 \%$ & 22.9 \\
\hline Lysine $_{49}$ & 12 & $\sim 5 \%$ & $13 \%$ & ND \\
\hline Lysine $_{\bar{x} 0}$ & & \multirow{9}{*}{$\sim 20 \%$} & ND & ND \\
\hline Lysine $_{83}$ & 10 & & $8 \%$ & 12.4 \\
\hline Lysine $_{112}$ & 13 & & $14 \%$ & ND \\
\hline Lysine $_{131}$ & $8 \mathrm{~A}$ & & $15 \%$ & 6.1 \\
\hline Lysine $_{133}$ & 4 & & $32 \%$ & ND \\
\hline Lysine $_{13 t}$ & 3 & & $25 \%$ & 5.3 \\
\hline Lysine $_{161}$ & $8 \mathrm{~B}$ & & $6 \%$ & ND \\
\hline Histidine $\bar{\gamma}$ & 11 & & $22 \%$ & ND \\
\hline Tyrosine $_{129}$ & 7 & & $23 \%$ & ND \\
\hline $\begin{array}{c}\mathrm{PEG}_{12 \mathrm{k}}-\mathrm{IFN} \text { alfa-2b } \\
\text { mixture } \\
\left(\mathrm{PEG}^{\left.-\mathrm{INTRON}^{8}\right)}\right.\end{array}$ & NA & $100 \%$ & $28 \%$ & $2.0 \sim 4.8$ \\
\hline $\begin{array}{c}\mathrm{PEG}_{40 \mathrm{x}} \text {-IFN alfa-2a } \\
\text { mixture } \\
\left(\mathrm{PEGASYS}^{8}\right)\end{array}$ & NA & $100 \%$ & $1 \%$ & $33 \sim 76$ \\
\hline
\end{tabular}

Positional isomers, defined by the residue attached to PEG, are listed ${ }^{32}$. For each positional isomer, the corresponding peak number is shown in the IE-HPLC chromatogram of Fig. 5. The cytopathic effect activities presented in the table are relative to the activity for unmodified interferon alfa- $2 \mathrm{~b}$.

$\mathrm{pH}$, which forms amide bonds with amine groups. The predominant positional isomers for $\mathrm{PEG}_{40 \mathrm{k}}{ }^{-}$ IFN alfa-2a are approximately equivalent populations of Lys31, Lys121, Lys131 \& Lys 134 with minor positional isomers at other lysine positions within the protein core. Thus, $\mathrm{PEG}_{40 \mathrm{k}}-\mathrm{IFN}$ alfa2a lacks the highly active His34 positional isomer that is the most abundant isomer in $\mathrm{PEG}_{12 \mathrm{k}}-\mathrm{IFN}$ alfa-2b. Furthermore, one of the major positional isomers in $\mathrm{PEG}_{40 \mathrm{k}}$-IFN alfa-2a, Lys31, has one of the two lowest STAT1 translocation activities.

In addition to the effect of the positional isomer distribution on biological activity, it has been previously shown that the size of the attached PEG group impacts the biological activity of pegylated interferons ${ }^{32)}$. Positional isomers Cys1, Lys31, His34, Lys83, Lys121, Lys131, Lys134 were generated with $5 \mathrm{kDa}, 12 \mathrm{kDa}, 20 \mathrm{kDa}$ and $30 \mathrm{kDa}$ PEG groups attached. In each case, an increase in the PEG molecular weight led to a decrease in biological activity. The size of the PEG groups attached to $P G_{40 k}-I F N$ alfa-2a and $\mathrm{PEG}_{12 \mathrm{k}}-\mathrm{IFN}$ alfa-2b are $40 \mathrm{kDa}$ (branched) and $12 \mathrm{kDa}$ (linear), respectively. Thus, differences in the sites of pegylation in conjunction with sizemediated steric hindrance provide a rationale for the difference in in vitro biological activities between PEG $_{40 k}-$ IFN alfa-2a $\left(\right.$ PEGASYS $^{\circledR}$ ) and $\mathrm{PEG}_{12 \mathrm{k}}-\mathrm{IFN}$ alfa-2b $\left(\mathrm{PEG}-\mathrm{INTRON}^{\mathrm{B}}\right)$.

\section{CMC strategy for regulatory approval}

Since pegylated interferons are typically mixtures of positional isomers that are unique 


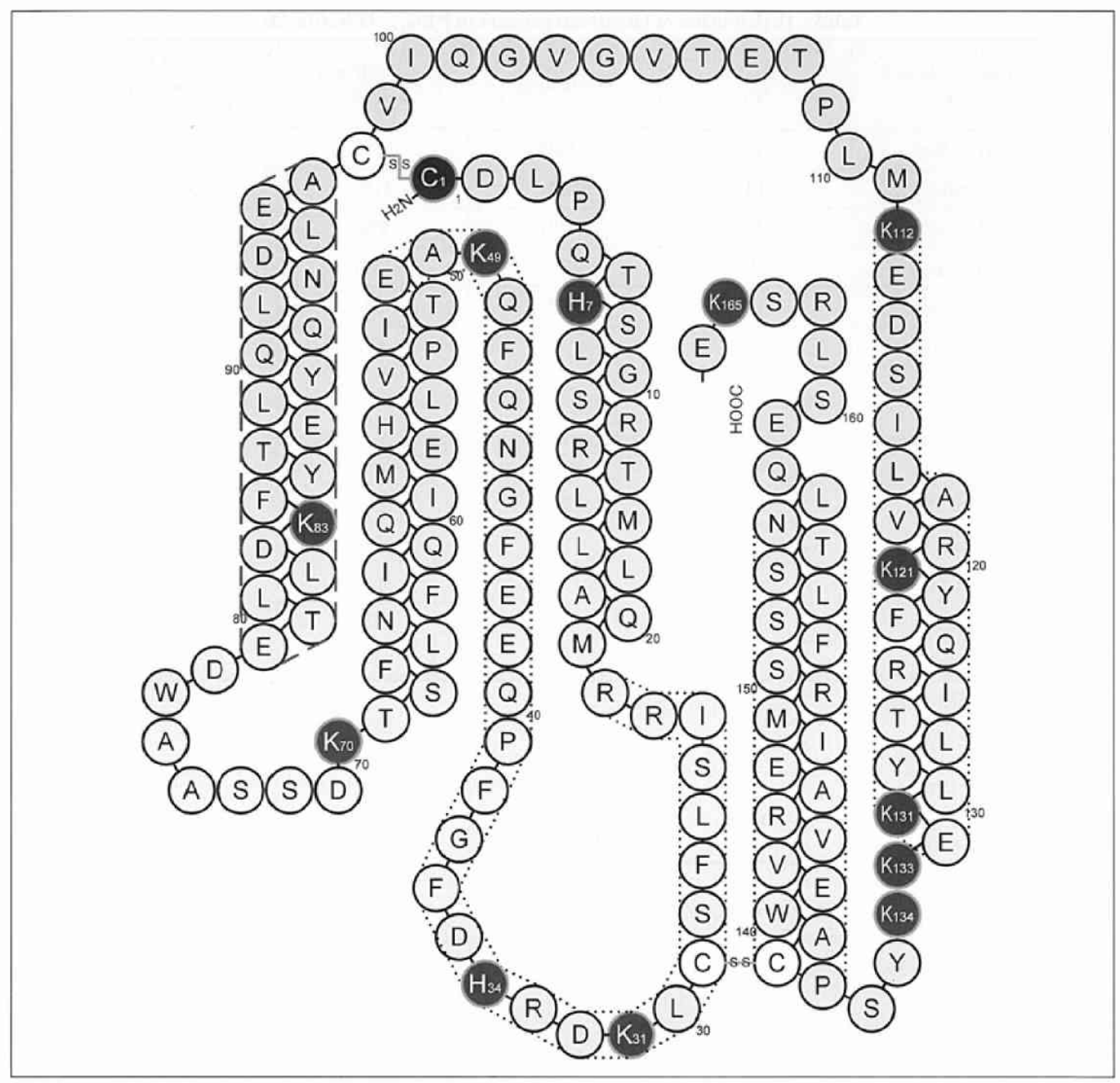

Fig.6 Annotated sequence of IFN alfa-2b

The sequence of IFN alfa- $2 b$ is shown as beads on a string. Residues involved in binding to the IFNAR2 receptor are outlined with a dotted line, while those involved with binding to the IFNAR1 receptor are outlined with a dashed line. Pegylated residues are shown as black (lysine, histidine, cysteine) beads. N- and C-terminals are noted as $-\mathrm{H}_{2} \mathrm{~N}$ and $-\mathrm{COOH}$, disulfide bonds are shown as gray lines denoted with "SS", and alfa helices as staggered double-wide arrays ${ }^{37.38 \%}$.

to their pegylation chemistries, their clinical safety and efficacy are inextricably linked to their pattern and extent of pegylation. Therefore, the successful CMC strategy for regulatory approval of PEG-INTRON ${ }^{\mathbb{R}}$ demonstrated that the quality of the pegylated interferon to be provided in the commercial drug product did not change significantly from that used in the clinical safety and efficacy trials. This was accomplished through extensive characterization and control of the pegylated interferon in the drug substance and drug product as well as appropriate control of the manufacturing processes.

The clinical and commercial PEG-INTRON ${ }^{\circledR}$ drug product is a lyophilized powder for injection containing $\mathrm{PEG}_{12 \mathrm{k}}-\mathrm{IFN}$ alfa-2b in strengths between 50 and $150 \mu \mathrm{g}$ per vial. Dosing is provided to patients on a $\mu \mathrm{g} / \mathrm{kg}$ basis. Other 
ingredients include sucrose, sodium phosphates, and polysorbate 80. A lyophilized formulation is necessary due to hydrolytic instability that can change the pegylation pattern in solution during long-term storage (36 months), but the product does not change during storage for 24 hours after reconstitution. It should be noted that the formulation imparts excellent stability to the product.

The pivotal clinical studies in hepatitis $\mathrm{C}$ were conducted with drug product lots that were manufactured at the commercial site of manufacture using drug substance manufactured at the commercial site and scale. Nine of the clinical batches were used to generate primary stability data for the product. Therefore, no comparability data to link the clinical and commercial products were required. Because of the structural complexity of PEG-INTRON ${ }^{\circledR}$, this strategy was considered crucial to avoiding delays in approval.

PEG-INTRON ${ }^{\circledR}$ characterization data, generated using the techniques previously described in this paper, were provided in the regulatory dossier. The data included structural confirmation of the different isoforms, quantification of the relative amounts of the isoforms using ion exchange HPLC and of the extent of pegylation using SE-HPLC, and characterization of the bioactivity of the $\mathrm{PEG}_{12 \mathrm{k}}$-IFN alfa-2b. Drug substance lots utilized throughout the development were analyzed to demonstrate the consistency of the $\mathrm{PEG}_{12 \mathrm{k}}-\mathrm{IFN}$ alfa-2b used during the clinical program.

Analytical methods and specifications for $\mathrm{PEG}_{12 \mathrm{k}}$-IFN alfa-2b drug substance and drug product were developed to ensure that the commercial product would be of consistent quality and would be comparable with the material used during the clinical program. A content assay (SE-HPLC) was used to quantify the amount of $\mathrm{PEG}_{12 \mathrm{k}}$-IFN alfa-2b in the drug substance and in the finished lyophilized product. Since the extent and location of pegylation are key product parameters relating structure to safety and efficacy, SE-HPLC and IE-HPLC were used to specify the drug substance and drug product. The relative amounts of di-pegylated, mono-pegylated and unpegylated interferon alfa-2b measured by SEHPLC were controlled. In order to provide IEHPLC specifications that are both meaningful and practical, the 15 separate peaks associated with different positional isomers were divided into six separate groups based on their proximity in the chromatogram and the extent of the chromatographic separation. Also, the most abundant species peak (His34) and the most stabilityindicating peak (free IFN) were not grouped with other peaks. Specification limits were then set on the six groups instead of individual peaks. Since incompletely resolved peaks were grouped together, variations due to chromatographic variability and not true pegylation differences were minimized.

The biological activity of $\mathrm{PEG}_{12 \mathrm{k}}-\mathrm{IFN}$ alfa-2b was measured using the cytopathic effect (CPE) assay. In the drug substance, a specific activity (IU/mg) specification was established to ensure that the inherent bioactivity of the $\mathrm{PEG}_{12 \mathrm{k}}$-IFN alfa- $2 \mathrm{~b}$ did not change from approximately $28 \%$ of native IFN alfa-2b. For the drug product, the target specific activity was used to set a biological activity for each vial strength.

Long-term stability data were provided to drug substance and drug product shelf-life dating. Drug substance stability data on three lots manufactured at the commercial site were provided to demonstrate that $\mathrm{PEG}_{12 \mathrm{k}}$-IFN alfa-2b showed no change in product parameters during storage at $-80^{\circ} \mathrm{C}$. Stability data on three lots each of the 50,100 and $150 \mu \mathrm{g}$ vials were generated at $5 \pm$ $3^{\circ} \mathrm{C}$ and $25 \pm 2^{\circ} \mathrm{C}$ for up to 36 months, and $40 \pm$ $2^{\circ} \mathrm{C}$ for up to 6 months. A study at $30^{\circ} \mathrm{C}$ for 12 months was also conducted. Statistical analyses of the stability-indicating assay data (SE-HPLC and IE-HPLC) were provided to demonstrate that the drug product would meet shelf-life specifications.

In order to provide drug substance and drug product of consistent quality, the manufacturing processes were extensively characterized and controlled. For each process, the critical process 
parameters that impacted isomer distribution and extent of pegylation were identified and controlled. For the drug substance manufacturing process, some parameters were related to the quality of materials used to prepare pegylation reagents (e.g. the diol content of the mPEG used), while others were typical processing parameters such as $\mathrm{pH}$, holding times, etc. Because $\mathrm{PEG}_{12 \mathrm{k}}{ }^{-}$ IFN alfa-2b has been found to be susceptible to hydrolysis during long-term storage in solution under certain conditions, processing times and conditions in aqueous media were a particular focus of in-process controls. Since manufacture of the lyophilized drug product utilizes an aqueous solution, appropriate controls were instituted to ensure that the final drug product would meet release and shelf-life specifications. In some cases, control of a drug substance attribute was tightened to allow a slight change during drug product manufacture : in other cases, the drug product process was controlled to ensure no change in the attribute from the drug substance. Descriptions of the in-process controls were provided in the appropriate sections of the dossier.

In general, regulatory agencies can be expected to be sensitive to the extent and pattern of pegylation of pegylated proteins. Specifications involving these attributes will be challenged to be as narrow as the data in the dossier support. Therefore, comprehensive process development is essential to ensure that the commercial drug substance and drug product manufacturing processes are robust and produce material consistent with the material used in clinical studies.

\section{Discussion}

There are dozens of PEG chemistries currently under evaluation for clinical development of pegylated peptides and proteins ${ }^{10)}$. The type of activated PEG linker utilized and the coupling techniques have a dramatic impact on the resulting product characteristics, such as the type and distribution of positional isomers and the retention of biological activity.

With the extensive knowledge base that is accumulating in the literature on pegylation chemistry, it is possible to develop and implement rational design of pegylated therapeutic proteins. With an understanding of the distribution of potential pegylation sites, their location on the target protein and the structural/functional impact of the attachment of PEG, a linker chemistry and reaction conditions can be selected which generate a pegylated protein product with specific desired characteristics. The predominant goal, an increase in serum half-life of the protein which is correlated to the size of the attached PEG moiety, can be balanced with the retention of biological activity by targeting specific sites of pegylation and selecting a PEG MW which retards clearance of the protein from the bloodstream while minimizing the adverse impact on biological activity. If the PEG selected is not large enough, the retention of specific biological activity may be high, but the pharmacokinetic properties of the protein may not be significantly improved. Hoffmann-La Roche pegylated IFN alfa-2a with $5 \mathrm{kDa}$ PEG, but the product was never marketed because the elimination half life for the conjugate was not greatly improved relative to that of the native protein ${ }^{39)}$ and incurred unsuccessful clinical results. Both $\mathrm{PEG}_{40 \mathrm{k}}-\mathrm{IFN}$ alfa-2a $\left(\mathrm{PEGASYS}^{\circledR}\right.$ ) and PEG $_{12 \mathrm{k}}-\mathrm{IFN}$ alfa-2b (PEG-INTRON ${ }^{\circledR}$ ) have improved pharmacokinetic profiles. However, the differences in pegylation chemistry and linker size result in different distributions of pegylated positional isomers and differential biological activity profiles in vitro.

Characterization of pegylated proteins is particularly challenging due to the complex heterogeneous composition of pegylated positional isomers in the purified product. However, a $\mathrm{CMC}$ requisite would be the implementation of analytical tools which measure the relative abundance and type of each positional isomer and show that this pattern is reproducible within the manufacturing process. Ion-exchange HPLC has 
been shown to possess the highest potential for resolving and quantitating the distribution and relative ratios of positional isomers. In addition to the analysis of the positional isomer composition, the product must also be monitored for the removal of impurities. Since the pegylation reaction is initiated with purified IFN and activated PEG linker, the impurities which are introduced at this step are all process-related and well-defined, consisting of unmodified IFN and multi-pegylated interferon species. Thus, size exclusion HPLC is the method of choice for analyzing the purity of the final product. Release specifications developed to monitor the performance of the process and for quality control are based primarily on both of these HPLC assays.

As demonstrated in the case of PEG-INTRON ${ }^{\circledR}$, a successful CMC regulatory strategy for pegylated interferons requires that the commercial drug substance and drug product processes reproducibly produce material that is consistent with the material used to demonstrate clinical safety and efficacy. The pegylated interferon should be extensively characterized. Drug substance and drug product specifications should be consistent with the clinical material and with the database used in the regulatory submission. The manufacturing processes must be fully characterized and controlled to produce material of consistent quality.

\section{References}

1) Wilson JA, Richardson CD : Hepatitis C virus replicons escape RNA interference induced by a short interfering RNA directed against the NS5b coding region. Journal of Virology 79(11) : 7050-7058, 2005.

2) Lauer GM, Walker BD : Hepatitis $C$ virus infection. New England Journal of Medicine 345: 41-52, 2001.

3) Choo QL, Kuo G,Weiner AJ, Overby LR, Bradley DW, Houghton $\mathrm{M}$ : Isolation of a cDNA clone derived from a blood-borne non-A, non-B viral hepatitis genome. Science $244: 359-362,1989$.

4) EASL International Consensus Conference on Hepatitis C : Consensus Statement. Journal of Hepatology 30:956-961. 1999.

5) Feld JJ, Hoofnagle JH : Mechanism of action of interferon and ribavirin in treatment of hepatitis C. Nature 436 : 967-972, 2005.

6) Wills RJ : Clinical pharmacokinetics of interferons. Clin
Pharmacokinet 19(5): 390-399, 1990.

7) Poynard T, Leroy V. Cohard M et al. : Meta-analysis of interferon randomized trials in the treatment of viral hepatitis C : effects of dose and duration. Hepatology 24 (4) : 778-789, 1996.

8) McHutchison JG, Gordon SC, Schiff ER et al. : Interferon alfa-2b alone or in combination with ribavirin as initial treatment for chronic hepatitis C. Hepatitis Interventional Therapy Group. N Engl J Med 339: 1485-1492, 1998.

9) Poynard T, Marcellin P, Lee SS et al, : Randomized trial of interferon alpha2b plus ribavirin for 48 weeks or for 24 weeks versus interferon alpha2b plus placebo for 48 weeks for treatment of chronic infection with hepatitis $\mathrm{C}$ virus. International Hepatitis Interventional Therapy Group (IHIT). Lancet $352: 1426-1432,1998$.

10) Roberts MJ. Bentley MD, Harris JM : Chemistry for peptide and protein PEGylation. Advanced Drug Delivery Reviews $54: 459-476,2002$.

11) Asselin $\mathrm{BL}:$ The three asparaginases. Comparative pharmacology and optimal use in childhood leukemia. Adv Exp Med Biol 457: 621-629, 1999.

12) Inada Y. Furukawa M. Sasaki H. Kodera Y. Hiroto M et al. : Biomedical and biotechnological applications of PEGand PM-modified proteins. Trends Biotechnol 13:86-91, 1995.

13) Kinstler OB, Brems DN, Lauren SL, Paige AG, Hamburger JB et al. : Characterization and stability of $\mathrm{N}$-terminally PEGylated rhG-CSF. Pharm Res $13: 996-1002,1996$.

14) Luxon BA, Grace M. Brassard D. Bordens R : Pegylated interferons for the treatment of chronic hepatitis $\mathrm{C}$ infection. Clin Ther 24:1363-1383, 2002.

15) Harris JM, Martin NE. Modi M : Pegylation : A novel process for modifying pharmacokinetics. Clin Pharmacokinet $40: 539-551,2001$.

16) Kozlowski A. Harris JM : Improvements in protein PEGylation : Pegylated interferons for treatment of hepatitis C, J Control Release 72:217-224, 2001.

17) Polyethylene Glycol Chemistry Biotechnological \& Biomedical Applications. (ed. Harris JM), New York: Plenum, 1992.

18) Glue P. Fang JW. Rouzier-Panis R et al. : Pegylated interferon-alpha2b : pharmacokinetics, pharmacodynamics, safety, and preliminary efficacy data. Hepatitis C Intervention Therapy Group. Clin Pharmacol Ther 68:556-567, 2000.

19) Nucci M, Shorr R, Abuchoweski A : The therapeutic value of poly (ethylene-glycol)-modified proteins. Advanced Drug Delivery Reviews 6:133-151, 1991.

20) Working P : Safety of poly (ethyleneglycol) and poly (ethylene glycol) derivatives. In Poly(ethylene glycol) : Chemistry \& Biological Applications. (eds. Harris JM, Zalipsky S). American Chemical Society. Washington, DC, 1997, p170-181.

21) Banci L. Bertini I. Caliceti P. Scolaro LM, Schiavon O et al. : Spectroscopic characterization of polyethyleneglycol modified superoxide dismutase proton NMR studies on its cobalt copper derivative. J Inorg Biochem 39:149-160. 1990.

22) Grace MJ. Bordens RW. Cutler DL : Peginterferons for the Treatment of Chronic Hepatitis C. HEPATOLOGY 2 : 3-9. Rev 2005.

23) Grace MJ. Cutler DL, Bordens RW : Pegylated interferons for chronic hepatitis $\mathrm{C}:$ an update. Expert Opin Drug Deliv 2(2) : 219-226, 2005.

24) Matthews SJ, McCoy C : Peginterferon alfa-2a : a review of approved and investigational uses. Clin Ther 7 : 
991-1025, 2004.

25) Lindsay KL. Trepo C, Heintges T, Shiffman ML, Gordon $\mathrm{SC}$ et al. : A randomized, double-blind trial comparing pegylated interferon alfa-2b to interferon alfa $-2 b$ as initial treatment for chronic hepatitis C. Hepatology 34 : 395-403, 2001.

26) Zeuzem S. Feinman SV, Rasenack J. Heathcote EJ, Lai MY et al. : Peginterferon alfa-2a in patients with chronic hepatitis C. New England Journal of Medicine 343: 1666-1672, 2000.

27) Heathcote E, Shiffman ML, Cooksley GE, Dusheiko GM, Lee SS et al, : Peginterferon alfa-2a in patients with chronic hepatitis $\mathrm{C}$ and cirrhosis. New England Journal of Medicine 343: 1673-1680, 2000.

28) Wylie DC. Voloch M. Lee S. Liu YH. Cannon-Carlson S et al. : Carboxyalkylated histidine is a $\mathrm{pH}$-dependent product of pegylation with SC-PEG. Pharm Res 18(9) : 1354-1360, 2001.

29) Na DH, Youn YS, Lee KC : Optimization of the PEGylation process of a peptide by monitoring with matrix-assisted laser desorption/ionization time-of-flight mass spectrometry. Rapid Commun. Mass Spectrom $17: 2241-2244,2003$.

30) Grace M. Youngster S, Gitlin G. Sydor W, Xie L et al. : Structural and biologic characterization of pegylated recombinant IFN-alfa $2 \mathrm{~b}$. J Interferon and Cytokine Res $21: 1103-1115,2001$.

31) Mossmann TR : Rapid colorimetric assay for cellular growth and survival : application to proliferation and cytotoxicity assays. J Immunol Methods $65: 55-63,1983$.

32) Grace MJ. Lee S, Bradshaw S, Chapman J, Spond J et al. : Site of pegylation and polyethylene glycol molecule size attenuate interferon-alfa antiviral and antiproliferative activities through the JAK/STAT signaling pathway. The Journal of Biological Chemistry 280:6327-6336, 2005.

33) Jorgensen KE, Moller JV : Use of flexible polymers as probes of glomerular size. American Journal of Physiology F103-110, 1979.

34) Wang YS, Youngster S, Grace M, Bausch J, Bordens RW et al. : Structural and biological characterization of pegylated recombinant interferon alpha- $2 b$ and its therapeutic implications. Adv Drug Deliv Rev $54: 547-570,2002$.

35) Grace MJ, Cutler DL : Pegylating IFNs at His34 improves the in vitro antiviral activity through the JAK/STAT pathway. Antiviral Chemistry \& Chemotherapy 15 : 287-297, 2004.

36) Roberts MJ, Harris JM : Attachment of degradable poly (ethylene glycol) to proteins has the potential to increase therapeutic efficacy. J Pharm Sci 87(11) : 1440-1445. 1998.

37) Radhakrishnan R. Walter LJ. Hruza A, Reichert P. Trotta PP et al. : Zinc mediated dimer of human interferonalfa $2 \mathrm{~b}$ revealed by $\mathrm{X}$-ray crystallography. Structure 4 : 1453-1463, 1996.

38) Roisman LC, Piehler J, Trosset JY, Scheraga HA, Schreiber G : Structure of the interferon-receptor complex determined by distance constraints from double-mutant cycles and flexible docking. Proc Natl Acad Sci USA 98 : 13231-13236, 2001.

39) Bailon P. Spence C, Schaffer CA et al. : Pharmacological properties of five polyethylene glycol conjugates of interferon alfa-2a. Antiviral Therapy 4 (Suppl. 4) : 27, 1999. 